Portland State University

PDXScholar

\title{
Migration Timing and Wintering Areas of Three Species of Flycatchers (Tyrannus) Breeding in the Great Plains of North America
}

\author{
Alex E. Jahn \\ University of Florida \\ Victor R. Cueto \\ Facultad de Ciencias Exactas y Naturales \\ James W. Fox \\ British Antarctic Survey \\ Michael S. Husak \\ Cameron University \\ Daniel H. Kim \\ Platte River Whooping Crane Maintenance Trust

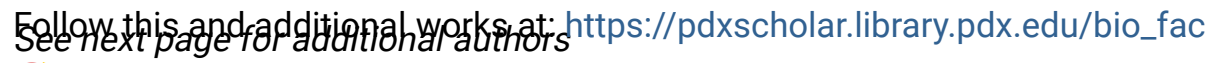 \\ Part of the Biology Commons, and the Ornithology Commons \\ Let us know how access to this document benefits you.
}

\section{Citation Details}

Jahn, Alex E., et al. "Migration Timing and Wintering Areas of Three Species of Flycatchers (Tyrannus) Breeding in the Great Plains of North America." Auk (University Of California Press) 130, no. 2 (April 2013): 247-257.

This Article is brought to you for free and open access. It has been accepted for inclusion in Biology Faculty Publications and Presentations by an authorized administrator of PDXScholar. Please contact us if we can make this document more accessible: pdxscholar@pdx.edu. 


\section{Authors}

Alex E. Jahn, Victor R. Cueto, James W. Fox, Michael S. Husak, Daniel H. Kim, Diane V. Landoll, Jesús

Pinto Ledezma, Heather K. LePage, Douglas J. Levey, Michael T. Murphy, and Rosalind B. Renfrew 


\title{
MIGRATION TIMING AND WINTERING AREAS OF THREE SPECIES OF FLYCATCHERS (TYRANNUS) BREEDING IN THE GREAT PLAINS OF NORTH AMERICA
}

\author{
Alex E. Jahn, ${ }^{1,2,13}$ Víctor R. Cueto, ${ }^{2}$ James W. Fox, ${ }^{3,4}$ Michael S. Husak, ${ }^{5}$ Daniel H. Kim, ${ }^{6}$ \\ Diane V. Landoll, ${ }^{7}$ Jesús Pinto Ledezma, ${ }^{8}$ Heather K. LePage, ${ }^{9}$ Douglas J. Levey, ${ }^{1,10}$ \\ Michael T. Murphy, ${ }^{11}$ and Rosalind B. Renfrew ${ }^{12}$ \\ ${ }^{1}$ Department of Biology, University of Florida, Gainesville, Florida 32611, USA; \\ ${ }^{2}$ Instituto de Ecología, Genética y Evolución de Buenos Aires (IEGEBA), Facultad de Ciencias Exactas y Naturales, Universidad de \\ Buenos Aires y CONICET, Ciudad Universitaria, C1428EHA, Buenos Aires, Argentina; \\ ${ }^{3}$ British Antarctic Survey, Natural Environment Research Council, High Cross Madingley Road, Cambridge, CB3 OET, United Kingdom; \\ ${ }^{4}$ Migrate Technology Ltd., P.O. Box 749, Cambridge, CB1 0QY, United Kingdom; \\ ${ }^{5}$ Department of Biological Sciences, Cameron University, Lawton, Oklahoma 73505, USA; \\ ${ }^{6}$ Platte River Whooping Crane Maintenance Trust, Wood River, Nebraska 68883, USA; \\ ${ }^{7}$ Department of Biology, University of Oklahoma, Norman, Oklahoma 73019, USA; \\ ${ }^{8}$ Museo de Historia Natural Noel Kempff Mercado, Av. Irala 565, Facultad de Ciencias Agrícolas, Universidad Autónoma \\ Gabriel René Moreno, Santa Cruz de la Sierra, Bolivia; \\ ${ }^{9}$ Department of Wildlife Ecology and Conservation, University of Florida, Gainesville, Florida 32611, USA; \\ ${ }^{10}$ National Science Foundation, 4201 Wilson Boulevard, Arlington, Virginia 22230, USA; \\ ${ }^{11}$ Department of Biology, P.O. Box 751, Portland State University, Portland, Oregon 97219, USA; and \\ ${ }^{12}$ Vermont Center for Ecostudies, P.O. Box 420, Norwich, Vermont 05055, USA
}

\begin{abstract}
Descriptions of intra- and interspecific variation in migratory patterns of closely related species are rare yet valuable because they can help assess how differences in ecology and life-history strategies drive the evolution of migration. We report data on timing and location of migration routes and wintering areas, and on migratory speed and phenology, of Eastern Kingbirds (Tyrannus tyrannus) from Nebraska and Oklahoma and of Western Kingbirds (T. verticalis) and Scissor-tailed Flycatchers (T. forficatus) from Oklahoma. Eastern Kingbirds primarily departed the breeding site in September, migrating to the Amazon Basin (Bolivia and Brazil), $>6,400 \mathrm{~km}$ from their breeding site, then used a second wintering site in northwestern South America (Colombia, Ecuador, and Peru) before returning to the breeding site in April. Western Kingbirds left Oklahoma in late July, migrating $>1,400 \mathrm{~km}$ to northwestern Mexico, then to central Mexico and finally to Central America before returning to Oklahoma in April. Scissor-tailed Flycatchers departed Oklahoma mainly in mid-October, migrating to Central America (El Salvador, Guatemala, Honduras, and Nicaragua), 2,600 km from the breeding site, remaining there until early April before returning to Oklahoma. Timing of migration appears to be tightly linked to molt. Early departure of Western Kingbirds from the breeding site appears to be timed so that they molt in the Sonoran Desert region during the monsoon, whereas Scissor-tailed Flycatchers remain at their breeding site to complete molt in late summer, when insect prey are abundant. Eastern Kingbirds delay molt until reaching South America where, possibly, abundant fruit supports molt. Received 15 January 2013, accepted 8 March 2013.
\end{abstract}

Key words: Eastern Kingbird, light-level geolocator, migration speed, Nebraska, Neotropics, Oklahoma, Scissor-tailed Flycatcher, Tyrannus, Western Kingbird, wintering area.

\section{La Fenología de la Migración y las Áreas de Invernada de Tres Especies de Atrapamoscas Tyrannus que se Reproducen en las Grandes Llanuras de América del Norte}

RESUMEN.-Las descripciones de variación intra- e inter-específica en los patrones migratorios de las especies estrechamente relacionadas son poco frecuentes, pero valiosas, ya que pueden ayudar a evaluar cómo las diferencias en su ecología e historia de vida influyen en la evolución de la migración. Presentamos datos sobre la fenología y la ubicación de las rutas migratorias y áreas de invernada, y sobre la velocidad y la fenología migratoria de Tyrannus tyrannus de Nebraska y Oklahoma, y de T. verticalis y T. forficatus de Oklahoma.

${ }^{13}$ E-mail: alexjahn77@yahoo.com

The Auk, Vol. 130, Number 2, pages 247-257. ISSN 0004-8038, electronic ISSN 1938-4254. (C) 2013 by The American Ornithologists' Union. All rights reserved. Please direct al requests for permission to photocopy or reproduce article content through the University of California Press's Rights and Permissions website, http://www.ucpressjournals com/reprintInfo.asp. DOI: 10.1525/auk.2013.13010 
Los T. tyrannus partieron del área de cría principalmente en septiembre, migrando a la Cuenca Amazónica (Bolivia y Brasil), >6400 km de su área de cría. Después, utilizaron un segundo sitio de invernada en el noroeste de América del Sur (Colombia, Ecuador y Perú), antes de volver al área de cría en abril. Los $T$. verticalis partieron de Oklahoma a finales de julio, migrando $>1400 \mathrm{~km}$ hasta llegar al noroeste de México. Luego se movieron al centro de México y finalmente a Centroamérica, antes de regresar a Oklahoma en abril. Los T. forficatus partieron de Oklahoma principalmente a mediados de octubre, migrando a Centroamérica (El Salvador, Guatemala, Honduras y Nicaragua), $2600 \mathrm{~km}$ de la zona de cría, donde permanecieron hasta principios de abril, antes de regresar a Oklahoma. La fenología de la migración parece ser estrechamente vinculada a la muda. Los T. verticalis aparentemente realizan una partida temprana del sitio de cría para que puedan mudar en la región del Desierto de Sonora durante el monzón, mientras que los T. forficatus permanecen en su área de cría para completar la muda a finales del verano, cuando los insectos que comen son abundantes. Los T. tyrannus retrasan su muda hasta llegar a América del Sur donde, posiblemente, aprovechan de una abundancia de fruta para mudar.

UNTIL RECENTLY, IT was nearly impossible to track long-distance movements of individual migrant songbirds. This changed with the application of miniature solar geolocator technology (Stutchbury et al. 2009, Bridge et al. 2011). In just a single year, geolocators can yield data comparable to banding thousands of birds over decades (e.g., Ryder et al. 2011). Geolocator technology has revolutionized our understanding of the migratory and overwintering strategies of songbirds worldwide, as demonstrated by many recent papers (e.g., Delmore et al. 2012, Schmaljohann et al. 2012, Seavy et al. 2012, Stach et al. 2012, Tøttrup et al. 2012), including those in this special feature of The Auk. Geolocators provide spatial and temporal data from across the annual cycle of migratory birds that, when combined with information on timing of reproduction and molt, produce an integrated view of annual events in a bird's life. Such data are vital for understanding the evolution of life-history diversity and, on a more practical level, for developing robust migratory connectivity (e.g., Fraser et al. 2012) and migratory network models (Taylor and Norris 2010). Data on migratory movements, including the identification of migratory stopover locations (e.g., Bayly et al. 2012), are vital for comprehensive species-management strategies (Peterjohn and Sauer 1999, Leu and Thomposon 2002, Faaborg et al. 2007, Møller et al. 2008). The potential contribution of geolocators to these goals cannot be overstated.

Indeed, our understanding of migratory bird biology in the non-breeding season has improved with technological advances. For instance, Schwartz (1964) used band returns to document high site fidelity and territoriality for some species of wintering migrant birds in the Neotropics (see also Bates 1992), whereas later studies used radiotelemetry to reveal that sizable floater populations sometimes exist in otherwise territorial species (Rappole and Warner 1980, Winker et al. 1990). Regardless, our perception was that migrants overwintered at a single geographic site. Geolocators have shown this to be true of some species (e.g., Wood Thrushes [Hylocichla mustelina]; Stutchbury et al. 2009), but they have also revealed a surprisingly different pattern: within a phylogenetically diverse group of species, including Veeries (Catharus fuscescens; Heckscher et al. 2011), Swainson's Thrushes (C. ustulatus; Delmore et al. 2012), Red-backed Shrikes (Lanius corullio; Tøttrup et al. 2012), and Fork-tailed Flycatchers (Tyrannus savana; Jahn et al. 2013), individuals use multiple wintering sites, the full significance of which has yet to be elucidated. Geolocators have also yielded data describing year-to-year variation in the migratory routes of individuals (Stanley et al. 2012).

Of the 34 species of tyrant flycatchers (Tyrannidae) that breed north of Mexico, 28 (82\%) overwinter in the Neotropics (Sibley 2000). Although these species are widely distributed across North America, our understanding of the details of their life cycle remains rudimentary because previous research on their migration relied solely on banding and specimen collections to infer migration routes, timing of migration, and migratory tendency (e.g., Chesser 2005, Cooper et al. 2009, Colorado 2010, Capllonch et al. 2011, Jahn et al. 2012). Most North American tyrannids appear to complete their annual molt away from the breeding grounds (Leu and Thompson 2002), but the degree to which they overlap molt and migration, or whether they complete the entire process on the wintering grounds, is unknown. The exception is the Western Kingbird (Tyrannus verticalis); studies of museum specimens conclude that adults vacate the breeding grounds for the region of the Mexican monsoon to complete their molt in late summer (Barry et al. 2009). Even more pressing is our need to delineate migratory phenology and pathways as well as the location of tropical wintering grounds, which remain unknown for even well-studied species such as the Western Kingbird.

Large tyrannids such as kingbirds (Tyrannus spp.) are ideal subjects for the application of geolocators because (1) their body mass (>30 g) allows them to carry geolocators relatively easily; (2) they have relatively high annual survival and site fidelity (Murphy 1996), which improves geolocator recovery; and (3) they use open habitats, preventing shading of the geolocator. Here, we use geolocators to describe variation in the timing of migration, the distance and speed of migration, and the location and number of sequential wintering areas occupied by individual Eastern Kingbirds (T. tyrannus), Western Kingbirds (T. verticalis), and Scissor-tailed Flycatchers (T. forficatus), three species of tyrannids that have overlapping breeding ranges across the southern Great Plains of North America. Our goals are to (1) describe interspecific variation in migratory biology for a group of closely related species that overlap greatly in body size, morphology, and ecology (Murphy 1989); (2) compare fall and spring migratory behavior; and (3) integrate the data that we collected with information on annual molt to provide a more comprehensive picture of the annual cycle of these species.

\section{Methods}

Study sites.-All individuals in our study bred in either Nebraska or Oklahoma. In Nebraska, Eastern Kingbirds were studied in riparian grasslands $\left(40.48^{\circ} \mathrm{N}, 98.26^{\circ} \mathrm{W}\right)$ characterized by wet meadow habitats and associated accretion forest (e.g., Eastern Cottonwood [Populus deltoides] and Slippery Elm [Ulmus rubra]). In southwestern Oklahoma, we studied Eastern Kingbirds, Western Kingbirds, and Scissor-tailed Flycatchers on the campus of Cameron University, Elmer Thomas Park, and the Lawton Country Club, all within $\sim 6 \mathrm{~km}$ of each other $\left(34.38^{\circ} \mathrm{N}, 98.24^{\circ} \mathrm{W}\right)$. These sites were characterized by mowed grass and mainly scattered oak trees (Quercus spp.). Scissor-tailed Flycatchers were also studied at Fort Sill Military Reservation, Oklahoma $\left(34.39^{\circ} \mathrm{N}, 98.29^{\circ} \mathrm{W}\right)$, 
an area composed of mixed forbs and grasses, with scattered mesquite (Prosopis spp.) and oak trees, and at the Wichita Mountains Wildlife Refuge, Oklahoma $\left(34.43^{\circ} \mathrm{N}, 98.37^{\circ} \mathrm{W}\right)$, which is characterized by mixed-grass prairie and stands of oak.

Field methods.-During July 2010, we captured 10 male Eastern Kingbirds in Nebraska. In June and July 2011, we captured two Eastern Kingbirds (1 female and 1 male), 40 Western Kingbirds (15 females and 25 males), and 38 Scissor-tailed Flycatchers (17 females and 21 males) in Oklahoma. All were captured using 38-mm-mesh mist nets placed near an active nest or within a territory. We often used conspecific vocalizations or a predator model to draw birds close to nets.

We banded each bird with an individually numbered federal band and a unique combination of three color bands. Birds were weighed, measured, sexed, and aged using standard methods (Ralph et al. 1993, Pyle 1997). We then attached a model Mk10S (15 mm, 30 stalk, $1.2 \mathrm{~g}$ ) or model Mk20ASLT (15 mm, $15^{\circ}$ stalk, 0.9 g; British Antarctic Survey [BAS], Cambridge, United Kingdom) archival light-level geolocator to each bird with a RappoleTipton leg-loop harness (Rappole and Tipton 1991), using Filament Kevlar (500 tex; Saunders Thread, Gastonia, North Carolina). The combined mass of geolocator and harness was $<4 \%$ body mass of the birds, all of which flew well upon release.

Analytical methods.-We analyzed data from geolocators using the single-threshold method (Lisovski et al. 2012) with the program suite BASTRAK (BAS). We adjusted for clock drift and visually inspected sunrise and sunset transitions using a lightlevel threshold of 3 to define sunrise or sunset, deleting those with very shallow slopes or with peaks in light intensity within $30 \mathrm{~min}$ of sunrise or sunset, eliminating an average of $32 \pm 4.6 \%$ (all statistics are reported as means $\pm \mathrm{SE}$ ) of the total number of days from deployment of the geolocators on the birds until their return to the breeding site.

Geolocator sensitivity was calibrated using on-bird data for 10 days immediately after deployment, while birds were still at the breeding sites and usually raising nestlings or fledglings. Because the sensitivity between locators may differ (Fox 2010) or because of differences between individuals in amount of shading of the locator (e.g., from small differences in the harness), and because we used different geolocator models at different latitudes, geolocators were calibrated individually for Eastern Kingbirds and Scissor-tailed Flycatchers. Because of highly variable transition data for most Western Kingbirds, we used data from one Western Kingbird with good transition data to calibrate the geolocators of all Western Kingbirds. This calibration resulted in sun elevation angles ranging from -5.8 to -4.0 for Eastern Kingbirds, -5.17 to -3.55 for Scissor-tailed Flycatchers, and a single angle of -4.82 for Western Kingbirds, which were used in subsequent analyses. For the calibration period, we calculated a mean error between the location of the birds (hereafter "point locality") and the location of the breeding site as $174 \pm 9.3 \mathrm{~km}$ (1.2 $2^{\circ}$ [0.09] latitude, $1.1^{\circ}$ [0.08] longitude) for Eastern Kingbirds; 133 $\pm 34.8 \mathrm{~km}\left(1.0^{\circ}[0.30]\right.$ latitude, $0.7^{\circ}[0.18]$ longitude) for Western Kingbirds; and $104 \pm 8.5 \mathrm{~km}\left(1.3^{\circ}[0.51]\right.$ latitude, $1.1^{\circ}[0.63]$ longitude $)$ for Scissor-tailed Flycatchers. We used midnight position fixes because these species are primarily diurnal migrants (Peterjohn 1989, Stevenson and Anderson 1994).

Throughout the course of the non-breeding season, there were extended periods ( $>20$ days) when the longitude of a given bird's point localities did not vary widely (typically $<8^{\circ}$ longitude). Because light-level estimations of longitude are more accurate than those of latitude (Fudickar et al. 2012, Lisovski et al. 2012), we define these as stationary periods (i.e., wintering areas), similar to previous studies (e.g., Heckscher et al. 2011, Stanley et al. 2012). We defined the departure date from the breeding site or from wintering areas as the first date on which there was a large change in longitude (typically $\geq 2^{\circ}$ ) without subsequent returns, and defined arrival date on a wintering area as the first day the longitude was within the range of longitudes recorded for the stationary period (excluding outliers; see below). Finally, we defined arrival at the breeding site in spring as the first day the longitude was within a degree of longitude of the breeding site. For some birds, changes in longitude were ambiguous and we were unable to calculate arrival and departure dates (and, therefore, rate of migration; Tables 1 and 2).

We defined fall migration distance as the straight-line distance between the breeding site and the average location of all the point localities that made up the wintering area. For birds with more than one wintering area, we used the first wintering area. We define spring migration distance as the straight-line distance between the average location of the point localities that made up the wintering area and the location of the breeding site. For birds with more than one wintering area, we used the last wintering area to measure the distance to the breeding site. The migration distances we report are therefore minimum distances traveled because birds likely did not migrate in a straight line between sites (Figs. 1 and 2). We define migration rate as the migration distance in fall or spring divided by the duration in days of the entire fall or spring migration period. Because of possible stopovers during migration, and because migration distances are minimum values, the migration rates that we report represent the minimum speed of the entire fall or spring migration journey.

To map wintering area(s) and migration routes, we excluded (1) point localities from 15 days before and after the fall and spring equinoxes (Fox 2010) because of high latitude uncertainties (but not for defining movement using changes in longitude, above), (2) those outside the known species range (based on data from InfoNatura and eBird; see Acknowledgments), (3) those that required movements of $\geq 1,500 \mathrm{~km} \mathrm{day}^{-1}$ (which is highly unlikely given our knowledge of these species), and (4) those over the ocean (except during migration). As a result, we did not create maps of wintering areas or migration routes of some birds, or calculate their distance or speed of migration (Table 2), because we were unable to determine the location of at least one wintering area. This was usually because all point localities during that time of winter were primarily north or south of the known winter range (InfoNatura). We suspect that the anomalous points were a result of artificially short photoperiods created by shading that resulted from extreme topography (i.e., shading due to nearby mountains results in shorter detected day lengths and, therefore, latitudinal error; Lisovski et al. 2012). Indeed, central Mexico and northern Central America, where Scissor-tailed Flycatchers and Western Kingbirds traveled through and overwintered, are largely hilly (e.g., Western Kingbirds occupy arid valleys in winter; Phillips 1994), and the Andes Mountains constitute a large portion of the Eastern Kingbirds' second wintering area in northwestern South America. For those birds for which we made maps, this data filtering resulted in the elimination of an average of $55 \pm 6.0 \%$ of days during migration and winter (in addition to the 15-day equinox period). 
TABLE 1. Individual fall departure dates from the breeding site and arrival at the wintering area (for those with $>1$ wintering area, date indicates arrival at the first wintering area), and spring departure dates from the wintering area and arrival at the breeding site. Breeding site is Nebraska for Eastern Kingbirds (EAKI) (except 1 from Oklahoma, denoted by "OK"), and Oklahoma for Western Kingbirds (WEKI) and Scissor-tailed Flycatchers (STFL). Includes those individuals for which insufficient data were available to construct maps of migration routes and wintering areas. Nebraska EAKI were fitted with light-level geolocators in 2010; all others were fitted with geolocators in 2011.

\begin{tabular}{|c|c|c|c|}
\hline Species & Sex & $\begin{array}{c}\text { Fall departure/ } \\
\text { arrival date }\end{array}$ & $\begin{array}{c}\text { Spring departure/ } \\
\text { arrival date }\end{array}$ \\
\hline EAKI (A) & $M$ & 7-Sep/30-Oct & 18-Apr/29-Apr \\
\hline EAKI (B) & $M$ & 3-Sep/28-Oct & 3-May/28-May \\
\hline $\mathrm{EAKI}(\mathrm{C})$ & $M$ & 9-Sep/29-Oct & 21-Apr/6-May \\
\hline EAKI (D) & $M$ & 24-Aug/16-Oct & 16-Apr/28-May \\
\hline EAKI (E) & $M$ & 2-Sep/24-Oct & 26-Apr/14-May \\
\hline EAKI (F) Year 1 & $M$ & 14-Sep/24-Sep & 17-Apr/10-May \\
\hline EAKI (F) Year 2 & $M$ & 6-Sep/23-Sep & 23-Apr/8-May \\
\hline EAKI (G) (OK) & $M$ & 11-Aug/6-Oct & 4-Apr/30-Apr \\
\hline WEKI (A) & $\mathrm{F}$ & 30-Jul/4-Aug & 27-Apr/- \\
\hline WEKI (B) & $\mathrm{F}$ & 29-Jul/7-Aug & -/2-May \\
\hline WEKI (C) & $\mathrm{F}$ & 17-Jul/23-Jul & 24-Apr/5-May \\
\hline WEKI (D) & $\mathrm{F}$ & 26-Jul/30-Jul & 24-Apr/5-May \\
\hline WEKI (E) & $\mathrm{F}$ & 17-Jul/30-Jul & 14-Apr/26-Apr \\
\hline WEKI (F) & $\mathrm{F}$ & 26-Jul/1-Aug & 23-Apr/9-May \\
\hline WEKI (G) & M & $-/ 25$-Jul & 20-Apr/28-Apr \\
\hline WEKI (H) & $M$ & 28-Jul/4-Aug & - \\
\hline WEKI (I) & M & 13-Jul/18-Jul & - \\
\hline WEKI (J) & $M$ & 21-Jul/5-Aug & 6-Apr/- \\
\hline WEKI (K) & M & 17-Jul/25-Jul & 5-Apr/- \\
\hline WEKI (L) & $M$ & 28-Jul/31-Jul & 23-Apr/ - \\
\hline WEKI (M) & $M$ & -/31-Jul & 17-Apr/- \\
\hline WEKI (N) & $M$ & -/20-Jul & 10-Apr/18-Apr \\
\hline STFL (A) & $\mathrm{F}$ & 21-Oct/27-Oct & 9-Apr/- \\
\hline STFL (B) & $\mathrm{F}$ & 22-Oct/1-Nov & 11-Apr/17-Apr \\
\hline STFL (C) & $\mathrm{F}$ & 2-Nov/17-Nov & 6-Apr/16-Apr \\
\hline STFL (D) & M & 18-Oct/4-Nov & 29-Mar/- \\
\hline STFL (E) & $\mathrm{F}$ & 20-Oct/27-Oct & 25-Mar/ - \\
\hline
\end{tabular}

We mapped wintering areas using kernel density estimator analysis (Silverman 1986, Terrell and Scott 1992) in the Spatial Analysis tool of ARCMAP, version 9.3 (ESRI, Redlands, California), using a search radius of $200 \mathrm{~km}$ and a grid-cell size of $2 \mathrm{~km}$ (e.g., Bächler et al. 2010). The average number of days used to map each wintering area was $28 \pm 5.4$. We estimated the location of migration routes using point localities that were consistent with the direction of migration and that did not require reversals in migration or successive days over the ocean. We then mapped routes as straight lines between these point localities using Hawth's Analysis Tools for ARCGIS, version 9.3 (Beyer 2004).

\section{Results}

Eastern Kingbirds.-Eight of 10 and 2 of 2 Eastern Kingbirds with geolocators returned to Nebraska in 2011 and to Oklahoma in 2012, respectively, and we recovered geolocators from 6 of 8 and 1 of 2. Additionally, we recovered a geolocator in 2012 from 1 of the Eastern Kingbirds in Nebraska that was not captured in
2011. Because of geolocator failure, usable data were available for 7 birds, including 2 years for the bird captured in Nebraska in 2012. The 6 Eastern Kingbirds from Nebraska (with 2 years of data for 1 bird) departed on fall migration in late August or early September, whereas the bird from Oklahoma initiated fall migration in early August (Table 1). Because of proximity to the equinox, there were too few points to determine the fall migration routes for most birds, but at least 1 bird (Fig. 1A) migrated to South America by crossing the Caribbean Sea, and another crossed the Gulf of Mexico (Fig. 1G). The 5 birds recaptured in 2011 in Nebraska and 1 bird recaptured in 2012 in Oklahoma arrived in the southern Amazon Basin (Bolivia and Brazil) from early to late October, $>6,400 \mathrm{~km}$ from the breeding site (Table 2 and Fig. 1). Residence time in this first wintering area averaged $100 \pm 11.3$ days before all individuals moved to a second wintering area in northwestern South America (Colombia, Ecuador, and northern Peru; Fig. 1), where they stayed an average of $75 \pm 12.2$ days. The individual with 2 years of data (Fig. 1F) differed from all other Eastern Kingbirds by using only one wintering area in both years. It remained in Colombia, Ecuador, and Peru (about $6^{\circ} \mathrm{N}-10^{\circ} \mathrm{S}$ ), in the area that became the second wintering area for other Eastern Kingbirds (Fig. 1), for an average of $208 \pm 4.0$ days before departing on spring migration.

Although some Eastern Kingbirds may be circum-Gulf spring migrants (Fig. 1A, C), most left South America in April and migrated north through Central America before crossing the Gulf of Mexico, departing from or near the Yucatán Peninsula (Fig. 1). Most of these trans-Gulf migrants likely made landfall in Texas, although one bird (Fig. 1B) entered the continent to the east, near the Alabama-Florida border. Arrival in Nebraska occurred over a 28-day period from late April to late May (Table 1).

The duration of fall migration for Eastern Kingbirds was more than twice the duration of spring migration, at least in part because the first winter location was south of the second winter location from which individuals began spring migration. Rate of spring migration was more than twice the rate of fall migration (Table 2; $277 \mathrm{~km} \mathrm{day}^{-1}$ vs. $127 \mathrm{~km} \mathrm{day}^{-1}$; paired $t$-test $=-2.88, \mathrm{df}=$ $5, P=0.035)$. There was no significant correlation between the date of departure from the wintering area in spring and arrival at the breeding site $(r=0.55, \mathrm{df}=5, P=0.202)$.

Western Kingbirds.-The return rate for Western Kingbirds in the year following geolocator deployment was $62.5 \%$ (25 of 40). We recovered 16 geolocators, 14 with usable data. Upon departure from Oklahoma in July (Table 1), Western Kingbirds flew southwest, primarily to the northwestern Mexican states of Baja California, Baja California Sur, and Sonora (Fig. 2), >1,400 km from the breeding site (Table 2). We detected no significant difference between sexes in migration distance $(t=0.87, \mathrm{df}=12, P=0.400)$, rate $(t=0.85, \mathrm{df}=8$, $P=0.421)$, or duration $(t=0.66, \mathrm{df}=8, P=0.530)$ of this initial leg of migration. They remained in northwestern Mexico until October, a period varying between 62 and 85 days (Fig. 2). Of the 5 individuals with usable data, all except 1 then moved to a wintering area in central Mexico, remaining there from October to December (Fig. 2). The individual that did not fit this pattern moved directly to Guatemala in November, remaining there until it departed in April for Oklahoma (Fig. 2H). The other 4 then moved in November or December to another wintering area (southern Mexico to northern Central America), where they remained until April (Fig. 2). Western Kingbirds arrived in Oklahoma from mid-April to early May (Table 1 and Fig. 2). 
TABLE 2. Individual migration histories (duration, distance, and speed of migration in fall and spring) of Eastern Kingbirds (EAKI) breeding in Nebraska (except 1 breeding in Oklahoma, denoted by "OK"), and of Western Kingbirds (WEKI) and Scissor-tailed Flycatchers (STFL) breeding in Oklahoma. Nebraska EAKI were fitted with light-level geolocators in 2010, whereas all others were fitted with geolocators in 2011. "ID" is the capitalized letter used to identify individuals in Figures 1-3. Fall migration distance represents the straight-line distance between the breeding site and the first wintering site, spring migration distance is the straight-line distance between the last wintering site and the breeding site, and speed is the straight-line migration distance divided by duration of migration.

\begin{tabular}{|c|c|c|c|c|c|c|c|}
\hline \multirow[b]{2}{*}{ Species (ID) } & \multirow[b]{2}{*}{ Sex } & \multicolumn{3}{|c|}{ Fall migration } & \multicolumn{3}{|c|}{ Spring migration } \\
\hline & & $\begin{array}{c}\text { Duration } \\
\text { (days) }\end{array}$ & $\begin{array}{c}\text { Distance } \\
(\mathrm{km})\end{array}$ & $\begin{array}{c}\text { Rate } \\
\left(\mathrm{km} \mathrm{day}^{-1}\right)\end{array}$ & $\begin{array}{l}\text { Duration } \\
\text { (days) }\end{array}$ & $\begin{array}{c}\text { Distance } \\
(\mathrm{km})\end{array}$ & $\begin{array}{c}\text { Rate } \\
\left(\mathrm{km} \mathrm{day}^{-1}\right)\end{array}$ \\
\hline $\operatorname{EAKI}(\mathrm{A})$ & $M$ & 53 & 6,673 & 126 & 11 & 5,293 & 481 \\
\hline EAKI (B) & $M$ & 55 & 7,052 & 128 & 25 & 5,616 & 225 \\
\hline EAKI (C) & $M$ & 50 & 6,945 & 139 & 15 & 5,171 & 345 \\
\hline EAKI (D) & $M$ & 53 & 6,442 & 122 & 42 & 5,177 & 123 \\
\hline EAKI (E) & $M$ & 52 & 6,967 & 134 & 18 & 5,048 & 280 \\
\hline EAKI (F) Year 1 & $M$ & - & 5,319 & - & 23 & 5,319 & 231 \\
\hline EAKI (F) Year 2 & $M$ & - & 5,588 & - & 15 & 5,588 & 373 \\
\hline EAKI (G) (OK) & $M$ & 56 & 6,510 & 116 & 26 & 4,779 & 184 \\
\hline Mean (SE) & & $53(0.9)$ & $6,578(207.4)$ & $127(3.4)$ & $22(3.8)$ & $5,220(102.9)$ & $277(44.2)$ \\
\hline WEKI (A) & $\mathrm{F}$ & 5 & 1,547 & 309 & - & 2,337 & - \\
\hline WEKI (B) & $\mathrm{F}$ & 9 & 1,306 & 145 & - & 2,074 & - \\
\hline WEKI (C) & $\mathrm{F}$ & 6 & 1,507 & 251 & 11 & 2,531 & 230 \\
\hline WEKI (D) & $\mathrm{F}$ & 4 & 1,555 & 389 & 11 & - & - \\
\hline WEKI (E) & $\mathrm{F}$ & 13 & 1,560 & 120 & 12 & - & - \\
\hline WEKI (F) & $\mathrm{F}$ & 6 & 1,320 & 220 & 16 & - & - \\
\hline WEKI (G) & $M$ & - & 1,371 & - & 8 & 2,608 & 326 \\
\hline WEKI $(\mathrm{H})$ & $M$ & 7 & 1,433 & 205 & - & 2,338 & - \\
\hline WEKI (I) & $M$ & 5 & 1,383 & 277 & - & - & - \\
\hline WEKI (J) & $M$ & 15 & 1,417 & 94 & - & - & - \\
\hline WEKI (K) & $M$ & 8 & 1,421 & 178 & - & - & - \\
\hline WEKI (L) & $M$ & - & 1,230 & - & - & - & - \\
\hline WEKI (M) & $M$ & - & 1,640 & - & - & - & - \\
\hline WEKI (N) & $M$ & - & 1,396 & - & 8 & - & - \\
\hline Mean (SE) & & $8(1.1)$ & $1,435(30.6)$ & $219(28.7)$ & $11(1.2)$ & $2,378(92.7)$ & $278(48.0)$ \\
\hline STFL (A) & $\mathrm{F}$ & 6 & 2,577 & 430 & - & 2,577 & - \\
\hline STFL (B) & $\mathrm{F}$ & 10 & 2,515 & 252 & 6 & 2,515 & 419 \\
\hline STFL (C) & $\mathrm{F}$ & 9 & - & - & 10 & - & - \\
\hline STFL (D) & $M$ & 16 & 2,704 & 169 & - & 2,704 & - \\
\hline STFL (E) & $\mathrm{F}$ & 7 & - & - & - & - & - \\
\hline Mean (SE) & & $10(1.7)$ & $2,599(55.6)$ & $284(77.0)$ & $8(2.0)$ & $2,599(55.6)$ & - \\
\hline
\end{tabular}

The initial leg of fall migration to northwestern Mexico was slower than spring migration from Central America, but small sample sizes preclude statistical comparisons. We mapped the spring migration route for 1 bird (Fig. 2C) overland through Mexico and Texas, back to Oklahoma. Among those birds with sufficient data (4 females and 2 males; Table 1), there was a positive and significant correlation between the date of departure from the wintering area in spring and arrival at the breeding site $(r=0.94, \mathrm{df}=4, P=0.006)$.

Scissor-tailed Flycatchers.-The return rate for Scissor-tailed Flycatchers was $44.7 \%$ (17 of 38) and we recovered 5 geolocators, all of which had usable data. None of the 5 Scissor-tailed Flycatchers departed the Oklahoma breeding site prior to 18 October (Table 1). Three individuals wintered in northern Central America (El Salvador, Guatemala, Honduras, and Nicaragua), on average 2,600 km from the breeding site (Table 2 and Fig. 2). Scissor-tailed Flycatchers migrated over the Gulf of Mexico during fall (Fig. 2), remained in the wintering area until late March to early April, and then returned to Oklahoma. Lack of data during spring migration precluded a definitive conclusion as to whether they are transGulf or circum-Gulf spring migrants (Fig. 2).

\section{Discussion}

Return rates of Eastern and Western kingbirds fitted with geolocators were high; for Eastern Kingbirds, they exceeded apparent annual survival rates reported from New York (0.690; Murphy 1996) and Oregon (0.649; Redmond and Murphy 2012). Return rates of Western Kingbirds were nearly as high, falling within the $95 \%$ confidence interval (CI) of apparent annual survival rates of Eastern Kingbirds (95\% CI: 0.560-0.728; Redmond and Murphy 2012). Geolocators thus appeared to have no negative influence on the probability of return in either species. Male Eastern Kingbirds exhibit higher site fidelity than females (Murphy 1996), and if the same is true for Scissor-tailed Flycatchers, the lower return rate of the latter species may be because only $55 \%$ of 


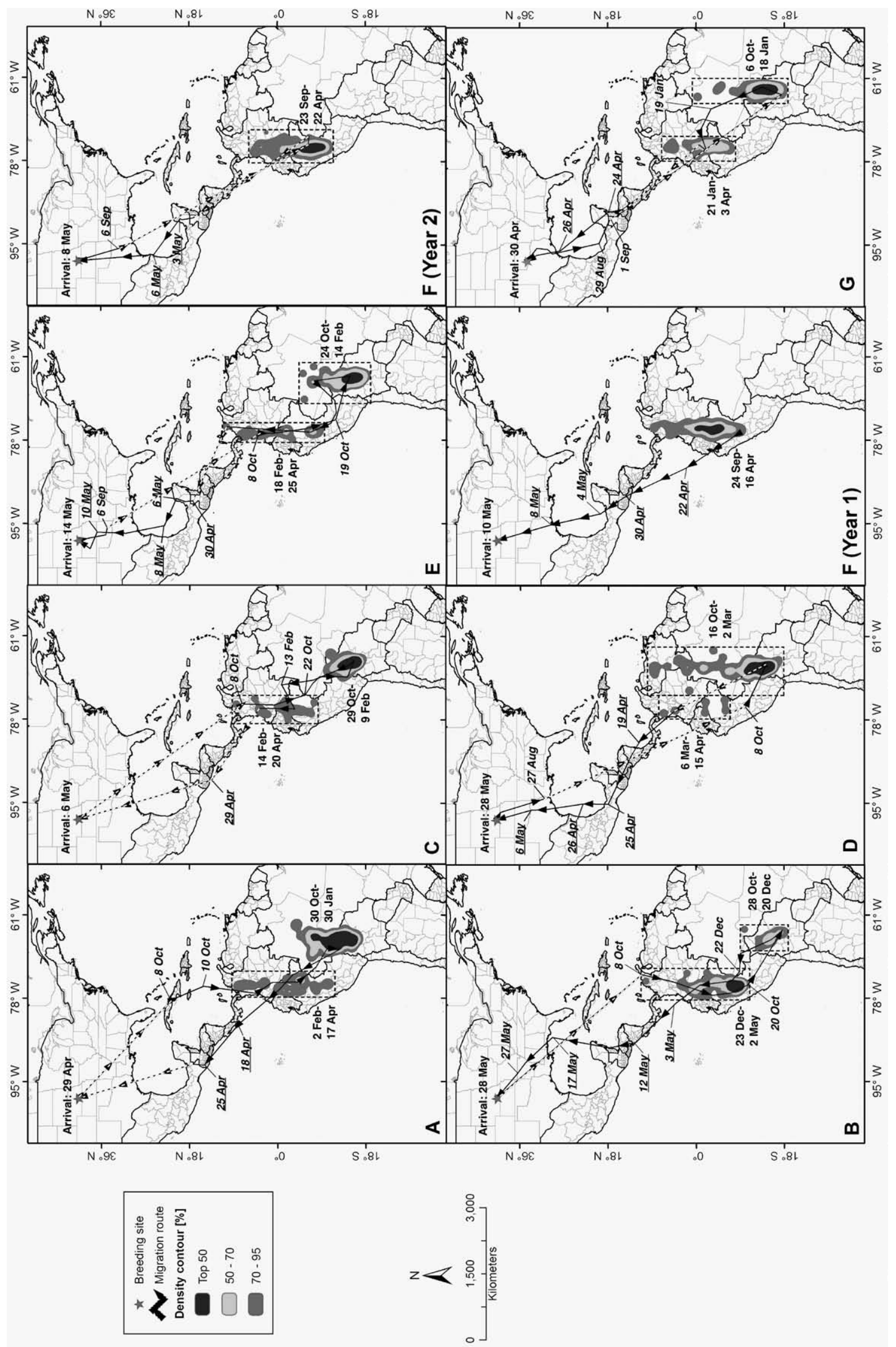

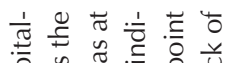

U

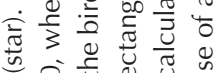

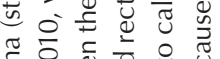

हิ

范

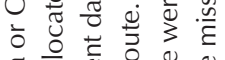

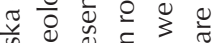

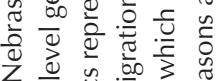

$\subseteq$ 亲.

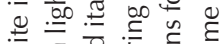

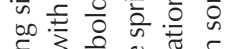

-

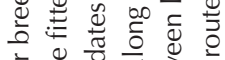

:

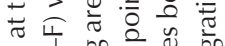

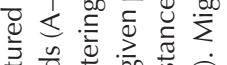

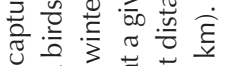

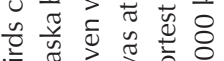

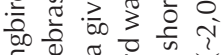

立 Z $\approx \stackrel{0}{=}$

둔

昰 $\frac{1}{0}$

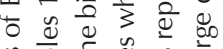

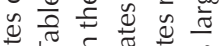

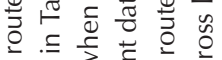

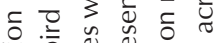

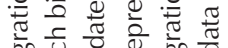

ह

তั

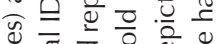

을 응 웡

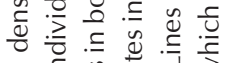

『 $\cong \frac{\pi}{3}$

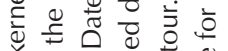

우요유

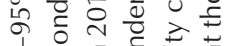

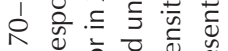

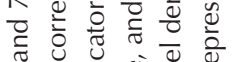

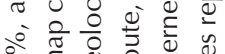

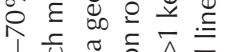

मी

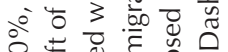

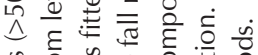

ส

ส

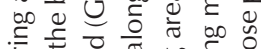

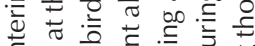

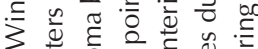

- U

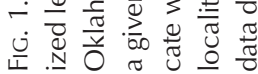




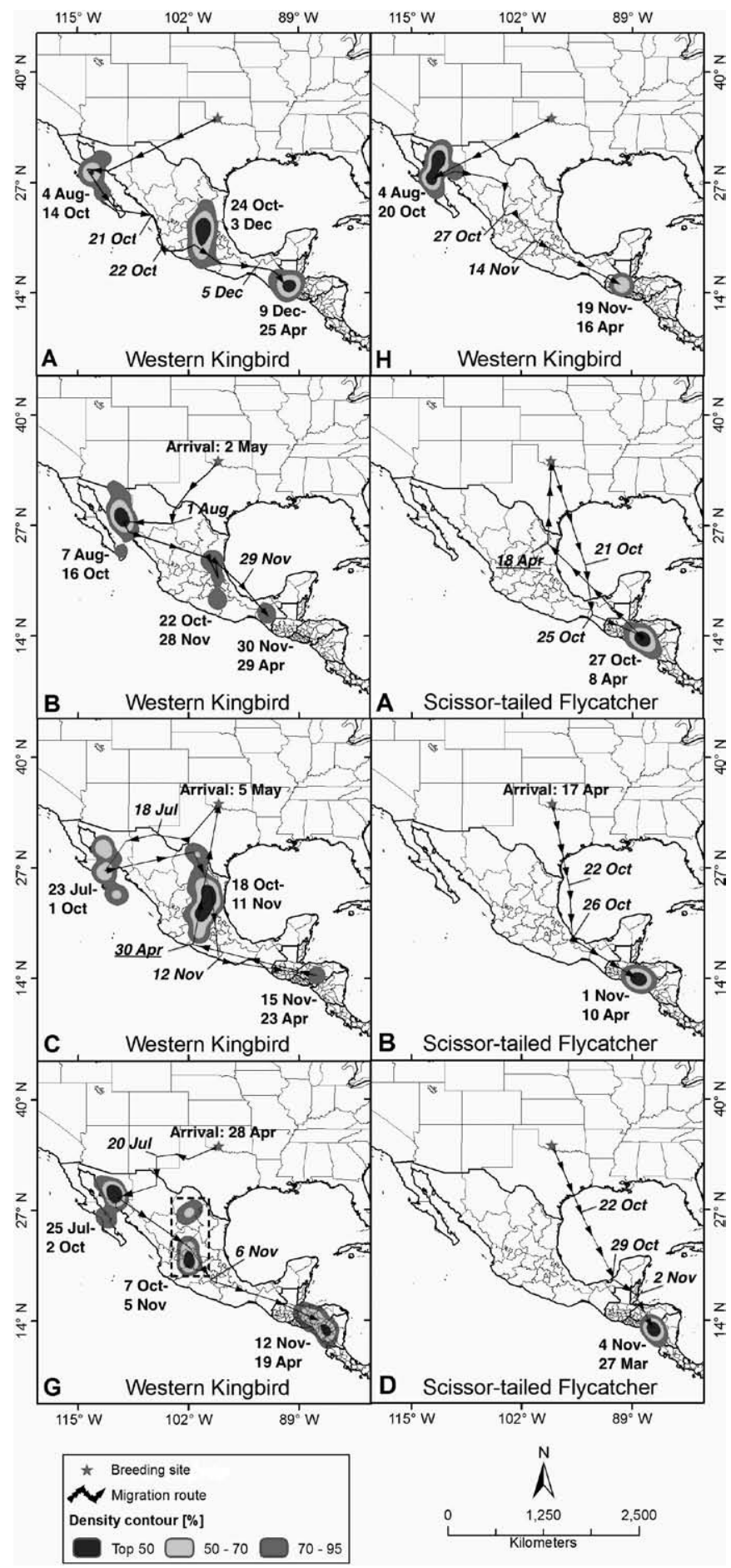

FIG. 2. Wintering areas (>50\%, 50-70\%, and 70-95\% kernel densities) and migration routes of Western Kingbirds and Scissor-tailed Flycatchers captured at their breeding site in Oklahoma (star) in 2011. Capitalized letters at the bottom left of each map correspond to the individual ID for each bird in Tables 1 and 2. See Figure 1 legend for an explanation of date codes, the dashed rectangle, and solid lines. Migration routes in some seasons are missing because of a lack of data during those periods.
Scissor-tailed Flycatchers that carried geolocators were male, compared with 92\% males in Eastern Kingbirds. However, we suspect that the low return rates of Scissor-tailed Flycatchers reveal more about interspecific differences in site tenacity than true survival, because both sexes of Scissor-tailed Flycatchers display high rates of inter-annual breeding dispersal (M. S. Husak and D. V. Landoll pers. obs.).

Our results also reveal large interspecific differences, along with moderate intraspecific variation, in the rate and timing of migration, existence of stopovers, and number of overwintering sites. For instance, Western Kingbirds left the Oklahoma breeding grounds toward the end of July, but Eastern Kingbirds delayed their departure until August or early September, and Scissortailed Flycatchers postponed their departure for 6 more weeks until at least mid-October (Table 1). In fall, Eastern Kingbirds migrated more slowly, on average, than Western Kingbirds and Scissor-tailed Flycatchers (Table 2), but more quickly than Fork-tailed Flycatchers (Jahn et al. 2013).

The late-summer departure of Western Kingbirds from the breeding grounds is consistent with observations of large numbers of Western Kingbirds in northwestern Mexico in late July (Barry et al. 2009). Our Eastern Kingbird arrival dates in the Amazon Basin likewise coincide with observations of Eastern Kingbird roosts numbered in the hundreds to thousands in eastern Bolivia in October (A. E. Jahn pers. obs.). The later fall departure of Scissor-tailed Flycatchers has been previously documented (Sutton 1967, Withgott 1991). Scissor-tailed Flycatchers arrived at their sole wintering site from Guatemala to Nicaragua by late October (Fig. 3), a region where the species is common to fairly common along the Pacific Slope in winter (Howell and Webb 1995).

By mid-December, Western Kingbirds began movement south to their second winter site, and by early March, Eastern Kingbirds moved north to their second winter site (Figs. 1 and 2). All three species then remained stationary until initiating spring migration (Fig. 3). One Eastern Kingbird took 42 days to return on spring migration, but all other birds returned in $<4$ weeks (Table 2 and Fig. 3), with most arriving on the breeding grounds before mid-May (Table 1). Scissor-tailed Flycatchers and Western Kingbirds took $\leq 16$ days to make their $>2,300 \mathrm{~km}$ return to the breeding site (Table 2 and Fig. 3), arriving by mid-April and early May, respectively (Table 1 ).

The positive relationship between date of departure from wintering grounds and arrival on breeding grounds in spring by the Western Kingbirds in our study is similar to that found for passerines in previous studies (Stanley et al. 2012, Callo et al. 2013); this may be due to the need to arrive as early as possible on breeding grounds to compete for territories or mates (reviewed by McKinnon et al. 2013).

Although we have limited data on migration paths, at least one Eastern Kingbird (Fig. 1A) and all Scissor-tailed Flycatchers appeared to cross the Gulf of Mexico in fall and headed south to southeast. Scissor-tailed Flycatchers made landfall near the Isthmus of Tehuantepec in southern Mexico, a region where transient Scissor-tailed Flycatchers are fairly common on fall migration (Howell and Webb 1995, Regosin 1998). In spring, most of the Eastern Kingbirds that we studied migrated through Central America, then over the Gulf of Mexico, departing from either the Yucatán or Isthmus of Tehuantepec (Fig. 1). Notably, data on 
eBird show a higher abundance of Eastern Kingbirds in the Yucatán in spring than in fall, and Eastern Kingbirds are regular spring migrants in Central America from mid-March (Ridgely and Gwynne 1989) to mid-May (Morton 1971). Reports of large numbers of Eastern Kingbirds on the barrier islands off the Gulf Coast of Mississippi in spring (Moore et al. 1990) are likewise consistent with trans-Gulf migration.

More data are needed to resolve migration routes of Western Kingbirds, though Gamble and Bergin (2012) report that Western Kingbirds migrate in fall along the Pacific coast. Previous observations also suggest that Western Kingbirds are likely not transGulf migrants in spring (Stevenson 1957, Oberholser 1974; but see Monroe 1968), which is supported by the one bird for which we had spring migration data (Fig. 2C).

Most Western and Eastern kingbirds used more than one site during the non-breeding season. Movement of Western Kingbirds from northwestern to central Mexico (see also Howell and Webb $1995)$ is likely tied to rainfall, because the predictably higher winter precipitation in eastern than in western Mexico (Magaña et al. 1999) may enhance primary productivity and food availability for overwintering migratory birds (e.g., Brown and Sherry 2006). Although partially frugivorous in summer (M. T. Murphy pers. obs.), Eastern Kingbirds are highly frugivorous in winter (Morton 1971, 1980). Morton (1971) suggested that Eastern Kingbirds remain nomadic for at least a portion of the northern winter as they track the abundant, but spatially variable, fruit upon which they feed heavily. Abundant fruit, and fruiting phenology across the Amazon Basin, may in part explain their use of more than one wintering area. Thus, temporal and spatial variation in rainfall and food availability may underlie the winter movements of both Eastern and Western kingbirds, as suggested for Fork-tailed Flycatchers (Jahn et al. 2013), Veeries (Heckscher et al. 2011), Red-backed Shrikes (Tøttrup et al. 2012), and Bobolinks (Dolichonyx oryzivorus; Renfrew et al. 2013).

Interestingly, although all but one Eastern Kingbird used more than one site, there was substantial variation in the timing of their movements between wintering areas; arrival dates at the second wintering area varied from 23 December to 6 March (Fig. 1). Such variation could be related to individual variation in the onset and duration of molt at the first wintering area (see below), or driven by socially mediated differences in access to resources at the first winter site; for example, socially subordinate individuals may depart earlier for the second winter site if access to food becomes limited at the first site. This scenario is speculative, however; we emphasize that the ecology and behavior of these species during the non-breeding season remain poorly known.

Timing of molt and migration.-Differences in the timing and location of molt among the study species are pronounced, revealing different adult molt strategies (Fig. 3). The timing of Eastern Kingbird molt is not well known (Fig. 3). However, A. M. Mamani and A. E. Jahn (unpubl. data) found that of 27 Eastern Kingbirds captured in eastern Bolivia in November 2008 (the same region occupied by some Eastern Kingbirds in the present study), $>80 \%$ had a medium to high body molt, and $>75 \%$ were molting flight feathers.

Barry et al. (2009) showed that in late summer, adult Western Kingbirds molt in the Sonoran Desert region of the southwestern United States and northwestern Mexico. The late July-early August arrival dates there of the Western Kingbirds we studied coincide with the timing of molt described by Barry et al. (2009), and the time spent there by the birds we studied (62-85 days) matches well with the time required by Western Kingbirds to complete molt (63 days [95\% CI: 56-69 days]; Rohwer and Broms 2012).

The mid- to late-October departure of Scissor-tailed Flycatchers from Oklahoma is known (Sutton 1967, Withgott 1991). The postbreeding residence period of $>2$ months on the breeding grounds allows adults to complete their annual molt before leaving on migration (Sutton 1986), which is consistent with the postbreeding residence period of most long-distance migrants from eastern North America (Leu and Thompson 2002).

Differences in the timing and location of molt are probably tied to differences in seasonality and food supply. The latesummer molt of adult Western Kingbirds appears to be timed, as it is in many western North American passerines (Rohwer et al. 2005, Barry et al. 2009), to take advantage of the pulse of food associated with the Mexican monsoon in the Sonoran Desert. By contrast, Scissor-tailed Flycatchers appear to take advantage of a late-summer peak in insect abundance in the southern Great
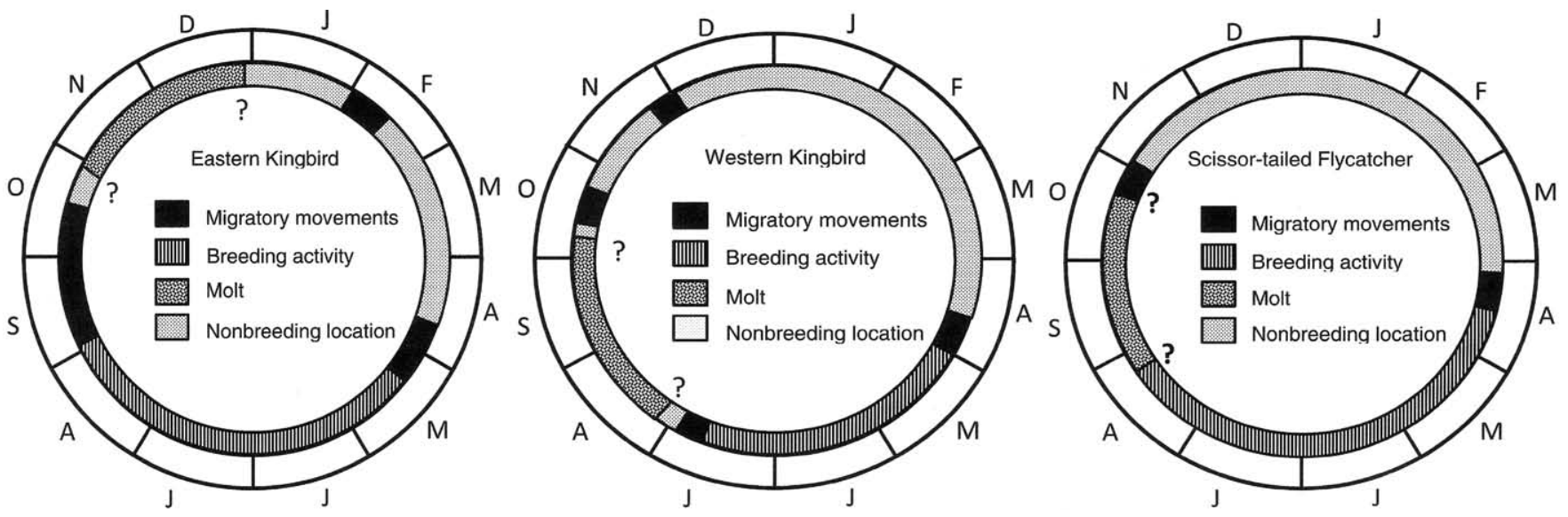

FIG. 3. Annual cycle of adult Eastern Kingbirds, Western Kingbirds, and Scissor-tailed Flycatchers generated from estimated dates of migration movements, and periods when birds remained stationary, based on light-level geolocator data. Molting periods were established on the basis of literature sources or personal observations of molting birds. Duration of molt was assumed to be approximately similar for all species and equal to that of Western Kingbirds ( 60 days); question marks represent uncertainty of the actual dates when, on a population level, molt began and was completed. 
Plains (Robins 1970, Murphy 1986), presumably making it possible for them to complete their molt before departing on migration.

Barta et al. (2008) predicted that winter molt, as found in Eastern Kingbirds, would be associated with relatively brief but high peaks of food abundance at both the breeding and wintering grounds. Eastern Kingbirds have the most northerly distribution of the three species, and, unlike in Scissor-tailed Flycatchers, climatic conditions deteriorate rapidly in early fall throughout much of their northern breeding range. By contrast, the southern Amazon Basin (the location of Eastern Kingbirds' first wintering area in our study) experiences substantial seasonality in rain and insect abundance, which increase after August (Jahn et al. 2010). Moreover, the long molt duration of tyrannids (63 days for Western Kingbirds [see above] and 69 days for Ash-throated Flycatchers [Myiarchus cinerascens], Butler et al. 2006; 62-79 days for Vermillion Flycatchers [Pyrocephalus rubinus], Butler 2013) likely selects against the start of molt on the breeding grounds by Eastern Kingbirds. Evolution of a more rapid molt as an alternative would possibly yield lower-quality feathers and/or gaps in the wings, which would compromise flight efficiency. Assuming a similarly long molt duration in Eastern Kingbirds, initiating molt in North America would delay departure until at least early October. Butler (2013) suggested that aerial sallying appears to favor slow molt, and for Eastern Kingbirds, this can only be accomplished by delaying molt until after migration.

Future directions.-Emerging technologies such as lightlevel geolocators offer a new way to understand the lives of migratory animals and will likely play a key role in both descriptive and hypothesis-driven research on migration in the near future (Bridge et al. 2011, McKinnon et al. 2013). Given that basic patterns, such as population connectivity, remain unresolved for most migrant passerines, descriptions of migratory movements and wintering areas remain a priority. The results of the present study raise several interesting questions for future research. (1) What drives the use of multiple wintering areas, and how do events in each wintering area carry over to the next wintering area and to the breeding grounds (e.g., Fraser et al. 2012, Macdonald et al. 2012, Callo et al. 2013)? (2) What are the evolutionary mechanisms responsible for specific migratory and/or molt strategies (e.g., rate of migration)? Comparative studies of conspecific populations breeding east to west across North America (Rohwer et al. 2005, Rohwer and Irwin 2011) and of congeners breeding at north- versus south-temperate latitudes could be useful because, for example, population-specific variation in their life-history strategies may mold their migratory strategies (Jahn and Cueto 2012). (3) What is the relationship between molt, migration, movements in winter, and climate within and between years? For example, northwestern Mexico-the molt-migration stopover site of Western Kingbirds-experiences higher than normal rainfall during the El Niño phase of the global climate cycle than during the La Niña phase (Magaña et al. 2003), which has been shown to be related to migratory bird survival in the region (LaManna et al. 2012). Therefore, given that adult Western Kingbirds go there to take advantage of the late-summer monsoon to molt (Barry et al. 2009), it may represent a better place to molt in some years than in others. Finally, (4) how do the relationships among migration timing and speed and the locations of migration routes and wintering areas vary between sexes, with age, and among years?

Understanding the complex life histories of migratory passerines, some of which may be better classified as intratropical migrants during the non-breeding season (e.g., Veeries [Heckscher et al. 2011], Swainson's Thrushes [Delmore et al. 2012], and Western and Eastern kingbirds in the present study), will require research at a finer grain and at broader spatial and temporal scales. As our understanding of their movements, physiology, and ecology during the non-breeding season accumulates, so too will our ability to develop appropriate conservation and management plans for these birds throughout their range.

\section{ACKNOWLEDGMENTS}

B. J. Stutchbury and two anonymous reviewers provided numerous comments that greatly improved the manuscript. We thank J. Kelly, the staff at Cameron University, the Crane Trust, Fort Sill Military Reservation, Lawton Country Club, Wichita Mountains Wildlife Refuge, the Museum of the Great Plains, and the City of Lawton for providing logistical support. P. Beal, V. Bejarano, R. Fox, J. I. Giraldo, V. Sandoval, and Q. Vidoz provided invaluable assistance in the field. This research was funded through a National Science Foundation (NSF) International Research Fellowship to A.E.J. (IRFP-0965213), a Scientific Research Grant (no. 8444-08) from the National Geographic Society, the Gatorade Fund of the University of Florida, and an NSF (IOS-0539370) and Faculty Enhancement Grant from Portland State University to M.T.M. eBird, an online database of bird distribution and abundance, is available at www.ebird.org/content/ebird. InfoNatura is available at www.natureserve.org/infonatura.

\section{Literature Cited}

Bächler, E., S. Hahn, M. Schaub, R. Arlettaz, L. Jenni, J. W. Fox, V. Afanasyev, and F. Liechti. 2010. Year-round tracking of small trans-Saharan migrants using light-level geolocators. PLoS ONE 5:e9566.

Barry, J. H., L. K. Butler, S. Rohwer, And V. G. Rohwer. 2009. Documenting molt-migration in Western Kingbird (Tyrannus verticalis) using two measures of collecting effort. Auk 126: 260-267.

Barta, Z., J. M. McNamara, A. I. Houston, T. P. Weber, A. Hedenström, And O. Feró. 2008. Optimal moult strategies in migratory birds. Philosophical Transactions of the Royal Society of London, Series B 363:211-229.

BAtES, J. M. 1992. Winter territorial behavior of Gray Vireo. Wilson Bulletin 104:425-433.

Bayly, N. J., C. Gómez, K. A. Hobson, A. M. GonzÁlez, And K. V. Rosenberg. 2012. Fall migration of the Veery (Catharus fuscescens) in Colombia: Determining the energetic importance of a stopover site. Auk 129:449-459.

Beyer, H. L. 2004. Hawth's Analysis Tools for ArcGIS. [Online.] Available at www.spatialecology.com/htools.

Bridge, E. S., K. Thorup, M. Bowlin, P. B. Chilson, R. H. Diehl, R. W. Fléron, P. Hartl, R. Kays, J. F. Kelly, W. D. Robinson, AND M. WiKelSKi. 2011. Technology on the move: Recent and forthcoming innovations for tracking migratory birds. BioScience 61:689-698.

Brown, D. R., AND T. W. Sherry. 2006. Food supply controls the body condition of a migrant bird wintering in the tropics. Oecologia 149:22-32. 
Butler, L. K. 2013. The grass is always greener: Do monsoon rains matter for molt of the Vermilion Flycatcher (Pyrocephalus rubinus)? Auk 130:297-307.

Butler, L. K., S. Rohwer, And M. Rogers. 2006. Prebasic molt and molt-related movements in Ash-throated Flycatchers. Condor 108:647-660.

Callo, P. A., E. S. Morton, and B. J. M. Stutchbury. 2013. Prolonged spring migration in the Red-eyed Vireo (Vireo olivaceus). Auk 130:240-246.

Capllonch, P., M. E. Álvarez, and P. G. Blendinger. 2011. Sobre la migración de Elaenia albiceps chilensis (Aves: Tyrannidae) en Argentina. Acta Zoológica Lilloana 55:229-246.

Chesser, R. T. 2005. Seasonal distribution and ecology of South American austral migrant flycatchers. Pages 168-181 in Birds of Two Worlds: The Ecology and Evolution of Migratory Birds (R. Greenberg and P. P. Marra, Eds.). Johns Hopkins University Press, Baltimore, Maryland.

Colorado, G. J. 2010. Fall migration of Empidonax flycatchers in northwestern Colombia. Journal of Field Ornithology 81: 259-266.

Cooper, N. W., M. T. Murphy, And L. J. Redmond. 2009. Ageand sex-dependent spring arrival dates of Eastern Kingbirds. Journal of Field Ornithology 80:35-41.

Delmore, K. E., J. W. Fox, And D. E. Irwin. 2012. Dramatic intraspecific differences in migratory routes, stopover sites and wintering areas, revealed using light-level geolocators. Proceedings of the Royal Society of London, Series B 279:4582-4589.

FaAborg, J., K. M. Dugger, And W. J. Arendt. 2007. Long-term variation in the winter resident bird community of Guánica Forest, Puerto Rico: Lessons for measuring and monitoring species richness. Journal of Field Ornithology 78:270-278.

Fox, J. W. 2010. Geolocator Manual, version 8. British Antarctic Survey, Cambridge, United Kingdom.

Fraser, K. C., B. J. M. Stutchbury, C. Silverio, P. M. Kramer, J. Barrow, D. Newstead, N. Mickle, B. F. Cousens, J. C. Lee, D. M. Morrison, AND OTHERs. 2012. Continent-wide tracking to determine migratory connectivity and tropical habitat associations of a declining aerial insectivore. Proceedings of the Royal Society of London, Series B 279:4901-4906.

Fudickar, A. M., M. Wikelski, And J. Partecke. 2012. Tracking migratory songbirds: Accuracy of light-level loggers (geolocators) in forest habitats. Methods in Ecology and Evolution 3:47-52.

GAmble, L. R., AND T. M. Bergin. 2012. Western Kingbird (Tyrannus verticalis). In Birds of North America Online (A. Poole, Ed.). Cornell Lab of Ornithology, Ithaca, New York. Available at bna. birds.cornell.edu/bna/species/227.

Heckscher, C. M., S. M. TAylor, J. W. Fox, and V. Afanasyev. 2011. Veery (Catharus fuscescens) wintering locations, migratory connectivity, and a revision of its winter range using geolocator technology. Auk 128:531-542.

Howell, S. N. G., AND S. WebB. 1995. A Guide to the Birds of Mexico and Northern Central America. Oxford University Press, New York.

Jahn, A. E., S. P. Bravo, V. R. Cueto, D. J. Levey, And M. V. MORALES. 2012. Patterns of partial avian migration in northern and southern temperate latitudes of the New World. Emu 112:17-22.

JAHn, A. E., AND V. R. Cueto. 2012. The potential for comparative research across New World bird migration systems. Journal of Ornithology 153 (Supplement 1):199-205.
Jahn, A. E., D. J. Levey, V. R. Cueto, J. P. Ledezma, D. T. Tuero, J. W. Fox, AND D. MAsson. 2013. Long-distance bird migration within South America revealed by light-level geolocators. Auk 130:223-229.

Jahn, A. E., D. J. Levey, A. M. Mamani, M. Saldias, A. Alcoba, M. J. Ledezma, B. Flores, J. Q. Vidoz, and F. Hilarion. 2010. Seasonal differences in rainfall, food availability, and the foraging behavior of Tropical Kingbirds in the southern Amazon Basin. Journal of Field Ornithology 81:340-348.

LaManna, J. A., T. L. George, J. F. Saracco, M. P. NotT, and D. F. DeSAnte. 2012. El Niño-Southern Oscillation influences annual survival of a migratory songbird at a regional scale. Auk 129:734-743.

LeU, M., And C. W. Thompson. 2002. The potential importance of migratory stopover sites as flight feather molt staging areas: A review for Neotropical migrants. Biological Conservation 106:45-56.

Lisovski, S., C. M. Hewson, R. H. G. Klaassen, F. KornerNievergelt, M. W. Kristensen, and S. Hahn. 2012. Geolocation by light: Accuracy and precision affected by environmental factors. Methods in Ecology and Evolution 3:603-612.

Macdonald, C. A., K. C. Fraser, H. G. Gilchrist, T. K. Kyser, J. W. Fox, AND O. P. Love. 2012. Strong migratory connectivity in a declining Arctic passerine. Animal Migration 1:23-30.

Magaña, V., J. A. Amador, and S. Medina. 1999. The midsummer drought over Mexico and Central America. Journal of Climate 12:1577-1588.

Magaña, V. O., J. L. VÁzquez, J. L. Pérez, And J. B. Pérez. 2003. Impact of El Niño on precipitation in Mexico. Geofísica Internacional 42:313-330.

McKinnon, E. A., K. C. Fraser, and B. J. M. Stutchbury. 2013. New discoveries in landbird migration using geolocators, and a flight plan for the future. Auk 130:211-222.

Møller, A. P., D. Rubolini, And E. Lehikoinen. 2008. Populations of migratory bird species that did not show a phenological response to climate change are declining. Proceedings of the National Academy of Sciences USA 105:16195-16200.

Monroe, B. L., JR. 1968. A distributional survey of the birds of Honduras. Ornithological Monographs, no. 7.

Moore, F. R., P. Kerlinger, and T. R. Simons. 1990. Stopover on a Gulf Coast barrier island by spring trans-Gulf migrants. Wilson Bulletin 102:487-500.

MorTon, E. S. 1971. Food and migration habits of the Eastern Kingbird in Panama. Auk 88:925-926.

Morton, E. S. 1980. Adaptations to seasonal changes by migrant land birds in the Panama Canal Zone. Pages 437-453 in Migrant Birds in the Neotropics: Ecology, Behavior, Distribution, and Conservation (A. Keast and E. S. Morton, Eds.). Smithsonian Institution Press, Washington, D.C.

Murphy, M. T. 1986. Temporal components of reproductive variability in Eastern Kingbirds (Tyrannus tyrannus). Ecology 67:1483-1492.

MurPHY, M. T.1989. Life history variability of North American breeding tyrant flycatchers: Phylogeny, size or ecology? Oikos 54:3-14.

Murphy, M. T. 1996. Survivorship, breeding dispersal and mate fidelity in Eastern Kingbirds. Condor 98:83-93.

Oberholser, H. C. 1974. The Birds of Texas, vol. 2. University of Texas Press, Austin. 
Peterjohn, B. G. 1989. The Birds of Ohio. Indiana University Press, Bloomington.

Peterjohn, B. G., and J. R. Sauer. 1999. Population status of North American grassland birds from the North American Breeding Bird Survey, 1966-1996. Pages 27-44 in Ecology and Conservation of Grassland Birds of the Western Hemisphere (P. D. Vickery and J. R. Herkert, Eds.). Studies in Avian Biology, no. 19.

Phillips, A. R. 1994. A tentative key to the species of kingbirds, with distributional notes. Journal of Field Ornithology 65:295-306.

PyLE, P. 1997. Identification Guide to North American Birds, Part 1: Columbidae to Ploceidae. Slate Creek Press, Bolinas, California.

Ralph, C. J., G. R. Guepel, P. Pyle, T. E. Martin, and D. F. DESANTE. 1993. Handbook of field methods for monitoring landbirds. U.S. Department of Agriculture, Forest Service General Technical Report PSW-GTR-144.

Rappole, J. H., and A. R. Tipton. 1991. New harness design for attachment of radio transmitters to small passerines. Journal of Field Ornithology 62:335-337.

Rappole, J. H., AND D. W. WARner. 1980. Ecological aspects of migrant bird behavior in Veracruz, Mexico. Pages 353-393 in Migrant Birds in the Neotropics: Ecology, Behavior, Distribution, and Conservation (A. Keast and E. S. Morton, Eds.). Smithsonian Institution Press, Washington, D.C.

RedMOND, L. J., AND M. T. MurPHy. 2012. Using complementary approaches to estimate survival of juvenile and adult Eastern Kingbirds. Journal of Field Ornithology 83:247-259.

Regosin, J. V. 1998. Scissor-tailed Flycatcher (Tyrannus forficatus). In Birds of North America Online (A. Poole, Ed.). Cornell Lab of Ornithology, Ithaca, New York. Available at bna.birds.cornell. $\mathrm{edu} / \mathrm{bna} / \mathrm{species} / 342$.

Renfrew, R. B., D. Kim, N. Perlut, J. Smith, J. Fox, and P. P. MARRA. 2013. Phenological matching across hemispheres in a longdistance migratory bird. Diversity and Distributions 19: in press

Ridgely, R. S., And J. A. Gwynne. 1989. A Guide to the Birds of Panama, with Costa Rica, Nicaragua, and Honduras, 2nd ed. Princeton University Press, Princeton, New Jersey.

Robins, J. D. 1970. The relationship of food supply to the timing of breeding in aerial foragers. Kansas Ornithological Society Bulletin 21:9-15.

Rohwer, S., AND K. Broms. 2012. Use of feather loss intervals to estimate molt duration and to sample feather vein at equal time intervals through the primary replacement. Auk 129:653-659.

Rohwer, S., L. K. Butler, And D. R. Froehlich. 2005. Ecology and demography of east-west differences in molt scheduling of Neotropical migrant passerines. Pages 87-105 in Birds of Two Worlds: The Ecology and Evolution of Migratory Birds (R. Greenberg and P. P. Marra, Eds.). Johns Hopkins University Press, Baltimore, Maryland.

Rohwer, S., AND D. E. IRWIn. 2011. Molt, orientation, and avian speciation. Auk 128:419-425.

Ryder, T. B., J. W. Fox, And P. P. Marra. 2011. Estimating migratory connectivity of Gray Catbirds (Dumatella carolinensis) using geolocator and mark-recapture data. Auk 128:448-453.

Schmaljohann, H., M. Buchmann, J. W. Fox, and F. Bairlein. 2012. Tracking migration routes and the annual cycle of a transSahara songbird migrant. Behavioral Ecology and Sociobiology 66:915-922.

Schwartz, P. 1964. The Northern Waterthrush in Venezuela. Living Bird 3:169-184.

Seavy, N. E., D. L. Humple, R. L. Cormier, and T. Gardali. 2012. Establishing the breeding provenance of a temperate-wintering North American passerine, the Golden-crowned Sparrow, using light-level geolocation. PLoS ONE 7:e34886.

Sibley, D. A. 2000. The Sibley Guide to Birds. Knopf, New York.

Silverman, B. W. 1986. Density Estimation for Statistics and Data Analysis. Chapman and Hall, New York.

Stach, R., S. Jakobsson, C. Kullberg, and T. Fransson. 2012. Geolocators reveal three consecutive wintering areas in the Thrush Nightingale. Animal Migration 1:1-7.

Stanley, C. Q., M. MacPherson, K. C. Fraser, E. A. McKinnon, AND B. J. M. STUtChbuRy. 2012. Repeat tracking of individual songbirds reveals consistent migration timing but flexibility in route. PLoS ONE 7:e40688.

Stevenson, H. M. 1957. The relative magnitude of the trans-Gulf and circum-Gulf spring migrations. Wilson Bulletin 69:39-77.

Stevenson, H. M., And B. H. Anderson. 1994. The Birdlife of Florida. University of Florida Press, Gainesville.

Stutchbury, B. J. M., S. A. Tarof, T. Done, E. Gow, P. M. Kramer, J. Tautin, J. W. Fox, and V. Afanasyev. 2009. Tracking long-distance songbird migration by using geolocators. Science 323:896.

Sutton, G. M. 1967. Oklahoma Birds. University of Oklahoma Press, Norman.

Sutton, G. M. 1986. Birds Worth Watching. University of Oklahoma Press, Norman.

TAYlor, C. M., AND D. R. NorRIs. 2010. Population dynamics in migratory networks. Theoretical Ecology 3:65-73.

Terrell, G. R., And D. W. Scott. 1992. Variable kernel density estimation. Annals of Statistics 20:1236-1265.

Tøttrup, A. P., R. H. G. Klaassen, R. Strandberg, K. Thorup, M. W. Kristensen, P. S. Jørgensen, J. Fox, V. Afanasyev, C. RAhbeK, AND T. Alerstam. 2012. The annual cycle of a transequatorial Eurasian-African passerine migrant: Different spatiotemporal strategies for autumn and spring migration. Proceedings of the Royal Society of London, Series B 279:1008-1016.

Winker, K., J. H. Rappole, and M. A. Ramos. 1990. Population dynamics of the Wood Thrush in southern Veracruz, Mexico. Condor 92:444-460.

Withgotт, J. H. 1991. Pre-migratory roosting behavior of Scissortailed Flycatchers in Oklahoma. Bulletin of the Oklahoma Ornithological Society 24:18-21.

Associate Editor: B. J. Stutchbury 